\begin{tabular}{l|l}
\hline SISTEMA \\
ELETRONICO \\
DE REVISTAS \\
SER I UfPR
\end{tabular}

\title{
Editorial
}

\section{Social Inequalities within Protected Natural Areas: An International Perspective}

\section{Desigualdades sociais em Áreas Naturais Protegidas: uma perspectiva internacional}

Over the last decade the increasing number of protected natural areas in both the Northern and Southern Hemispheres has brought the issue of environmental justice to the forefront. The creation of protected natural areas has resulted in regulation (ranging from restrictions to prohibited access) regarding the extraction of resources, land occupation and access to amenities. Such regulation indeed affects both local and external uses of protected areas in different ways, including in the form it takes, for example, whether traditional or contemporary. Regulation may also affect different users differently, at times privileging wealthy users over those with fewer resources.

This thematic issue provides critical analyses of the social and historical construction of protected natural areas and also addresses different forms of inequality (social, economic, ethnic, spatial...) that characterize access to and use of natural areas.

Access to natural amenities is often viewed as a "rich people's problem", of secondary importance in a context of environmental "crisis". This view nevertheless overlooks the driving role such access had in the first nature conservation and green movements and perpetuates, without questioning, the assumption that access to natural amenities is not important for the poor. Conversely, access to natural resources is perceived as more essential, as something that conditions the lives of present and future generations and their capacity for development. A resource or amenity is always more than just a resource or amenity, however, since one may actually become the other depending on how they are used by societies and social groups. In order to protect a heritage landscape, for example, access to some locally used resources might be forbidden. And biodiversity - viewed by current environmental research and policy as a priority - is defined as both a resource and an amenity. Without denying the significant differences in their uses and (more or less vital) importance, this thematic issue will address unequal access to resources and amenities without considering them to be two distinct types of environmental inequalities.

Environmental inequality is commonly accepted as an inequality in the relationship between people or social groups and their environment. It translates not only into unequal access to resources 
and amenities but also has other forms which can be interrelated: overexposure to risk, the production and transfer of environmental hazard, the ability to participate in collective action or shape environmental policy, or to benefit from their effects (Pye et al., 2008). Unequal access can as such be more broadly defined, according to J. Ribot and N. Peluso (2003), as an unequal capacity to benefit from a healthy and fruitful environment. This capacity is enabled or limited not only by a "bundle of rights" but also by a "bundle of powers", inherent to "the social and the political-economic contexts which shape people's abilities to benefit from resources" (ibid: 173). It is therefore necessary to analyze the essential issues bound up in obtaining, maintaining and controlling such access (Ribot and Peluso, ibid).

It is from this perspective that criticism of protected natural areas, ecological discourse and representations of the Human-Nature relationship has developed.

From an Environmental Justice perspective, M-M Evans (2008) has used American literature to point up the overlap between representations of nature and social identity: the "authentic American" figure is constructed around a wilderness experience - a ritualized encounter that "naturalizes" the identity of white heterosexual men in American society. All "Others" - i.e., people of other genders, races or sexual orientation - are perceived as "Intruders" when they attempt to have the same experience. They expose themselves to a number of social sanctions if they do not censor themselves. Such a paradigm implies - according to the author - that some groups of people are less deserving than others, not only in terms of access to nature but also with regard to the right to live in a safe environment. Access to nature and the related definition/ construction of nature itself are issues frequently overshadowed by social and environmental justice
- and they as such often resurface when protected areas are created.

W. Cronon (1996) has highlighted the legacy of colonial discourse passed down from the European colonization of the Third-world when it was considered that the mere presence of indigenous people was harmful to natural resources and they were deemed to be an indicator of environmental degradation. According to the author, subsequent scientific discourse on environmental destruction perpetuated this tradition, biased by an "imaginary wilderness" (Lochet, 2009) and prejudice against peoples in former colonies and their use of natural resources. R. Neumann's work (2005) has further shown that the western representation of "wilderness as nature is a powerful metaphor in struggles over the control and use of natural resources", justifying state intervention and the supervision of indigenous peoples.

This analysis offers a more critical view of the colonial legacy and the liberal system more broadly. Such criticism has been further developed by $\mathrm{N}$. Peluso (2012), for whom the strength of the liberal system lies in its ability to commodify nature. The production of such commodities has changed the uses of nature and made its access an economic issue and a topic of increasing and unequal regulation. This, in turn, has led to the development of new institutions and reasoning that have increased the vulnerability of populations who depend on and consume its resources (Peluso, 2012). For Peluso (2012, p. 40), nature and capitalism as such resemble "Beauty and the Beast" or "two sides of the same coin".

Although not as radical, several French environmental sociologists began to voice similar criticism in the 1980s and 1990s. B. Kalaora (1998) has argued that, far from challenging "rising industrialism" and the exploitation of nature, the first French national parks - a colonial legacy - were 
based on planning rationale which aimed to "reconcile modernity and nature, for the benefit of an elite eager to develop its spiritual and physical abilities" (Kalaora, 1998, 175, translated here). Similarly, J. L. Fabiani (1985, p. 86, translated here) has argued that: "Establishing 'nature reserves' and 'protected areas' works to both reinforce the representation of true nature as non-socialized and to establish a separation between natural nature and ordinary nature" which can then proceed to be destroyed freely.

Criticism over protected areas has always divided the scientific community, in which many worry, like environmental managers, that criticism could work against the achievement of commendable ends that are often jeopardized by other political and economic priorities. But it has also made it possible to highlight the impediments to the protection of nature by pointing up the importance of the socio-political and economic contexts in which protection or conservation measures are implemented. Still considered taboo or inappropriate a few years ago, issues related to environmental inequality and justice within protected areas have been increasingly recognized as legitimate and unavoidable, including in the eyes of managers pressured by demands for efficiency and justice.

The need to create protected areas with more or less restrictive statuses (cf. IUCN classification) ${ }^{1}$ has not been challenged and has indeed been reaffirmed at both the international scale (the 1992 Convention on biological biodiversity and the 20112020 Strategic Plan for Biodiversity) ${ }^{2}$ and local level. Nevertheless, ecological paradigms as well as the political and legislative contexts in which these protected areas are developed have evolved. In theory at least, they are generally more favorable to the recognition of indigenous knowledge and practices when defining and governing protected areas. But what about in practice? What changes and continuity can be observed in different types of protected areas, on different continents or countries, and in different local contexts? What are the concrete effects in terms of environmental inequality?

The articles gathered in this thematic issue offer insight into current research conducted on several continents: in Latin America, Europe, Africa and Asia. They address and nourish debate around four horizontal questions: (1) How far (and why) have processes leading to the creation of protected natural areas (contemporary or historical) resulted in inequalities in access and use? (2) Do international environmental policies promoting the Rio Declaration objectives of "public awareness and participation" contribute to reducing unequal access to natural amenities? (3) What principles of justice govern the arguments mobilized by the different stakeholders involved in the consultations, negotiations or conflicts over the creation, management and use of protected natural areas? (4) How does this governance of natural areas in turn interact with other international and national environmental policies and with related international programs?

The analyses gathered here highlight cases of intersectionality in both the North and South that underscore an "array of domination mindsets" (Fassin 2015, translated here). Nevertheless, "if the complexity of domination mindsets and power relationships is universal, intersectionality takes on specific meaning depending on where it plays out" (Fassin 2015: 20, translated here). The following case studies highlight the influence of history, political and cultural contexts on different forms of con-

\footnotetext{
1 https://www.iucn.org/theme/protected-areas/about/protected-areas-categories

2 https://www.cbd.int/
} 
temporary environmental inequality. In the North, the massification of leisure activities is a prevailing issue that has confronted the democratization of access to protected areas with the issue of protecting aestheticized nature. In the South, the issue of access to resources remains central: subsistence or commercial practices surrounding fishing, farming and hunting, as well as the cultivation of land are weighed against environmental policies. In postcolonial and post-apartheid contexts environmental inequality further takes on a strong ethno-racial dimension. This North-South divide is permeable and evolving, however. Ultimately, it is North-South relations that are examined, including within territories themselves, and the impediments to environmental justice at both the local and global scale.

\section{Valérie Deldrève Cécilia Claeys Organizers}

\section{References}

Cronon, W. The trouble with wilderness: or, getting back to the wrong nature. Environmental History, p. 7-28, 1996.

Evans, M. M. La "nature" et la justice environnementale. Ecologie et Politique, 1(35), 33-45, 2008.

Fabiani, J.-L. Science des écosystèmes et protection de la nature. In: Cadoret, A. (Ed.). Protection de la nature. Histoire et idéologie. De la nature à l'environnement. Paris: L'Harmattan, 1985. p. 75-90.

Fassin, E. D'un langage l'autre: l'intersectionnalité comme traduction. Raisons Politiques, 2(58), 9-24, 2015. Doi: 10.3917/rai.058.0009

Kalaora, B. Au-delà de la nature l'environnement. L'observation sociale de l'environnement. Paris: L'Harmattan, 1998.

Lochet, F.; Quénet G. L'histoire environnementale: origi- nes, enjeux et perspectives d'un nouveau chantier. Revue d'Histoire Moderne et Contemporaine, 4(56), 7-38, 2009.

Neumann, R. Making Political Ecology. London and New York: Hodder Arnold, 2005.

Peluso, N. Situer les political ecologies: l'exemple du caoutchouc. In: Gautier D.; Benjaminsen T.-A. (Eds.). Environnement, discours et pouvoir. L'approche Political ecology. Versailles: Quae, 2012. p. 37-74

Pye, S.; Skinner, I.; Meyer-Ohlendorf, N.; Leipprand, A.; Lucas, K.; Salmons, R. Addressing the social dimensions of environmental policy: A study on the linkages between environmental and social sustainability in Europe. Bruxelles: European Commission, 2008.

Ribot, J.; Peluso, N. A Theory of Access. Rural Sociology, 2(68), 153-181, 2003.

\section{Editorial and Technical staff responsible for this volume:}

Special section "Social Inequalities within Protected Natural Areas: An International Perspective". Organizers: Valérie Deldrève and Cécilia Claeys

Special section "Gestão Integrada de Áreas Litorais: Governança para os Serviços Ecossistêmicos das Costas e Oceanos". Organizers: Marinez E. G. Scherer e Milton L. Asmus

Chief-Editors: Angela Duarte Damasceno Ferreira and José Milton Andriguetto Filho

Assistant Editors: Frederico Monteiro Neves, Ricardo Ojima amd Thiago Zagonel Serafini

Scientific Secretariat: Ana Paula Debastiani Vasco, Letícia da Costa da Silva, Roberta Giraldi Romano and Tatiana Cristina Guimarães Kaminski

Referees: see at <http://ojs.c3sl.ufpr.br/ojs2/index.php/made/about/editorialPolicies\#custom-2>.

Proofreading (Portuguese): Reinaldo Cezar Lima

Proofreading (Abstracts): Fadille Terezinha Nabbouh

Desktop publishing: Reinaldo Cezar Lima

Design: Oscar Reinstein

ISSN: 1518-952X, eISSN: 2176-9109 